$$
\text { DOE/CE/283/2-T2 }
$$

\title{
WRAP Program Evaluation
}

\author{
Prepared by \\ Steven Ferrey \\ Professor of Energy Law \\ 1990
}

Companion Document to

Program Evaluation:

Weatherization Residential

Assistance Partnership

(WRAP) Program

ICF Resources Incorporated

December 1991

Prepared for

Northeast Utilities

WRAP Task Force 
WRAP PROGRAM EVALUATION

TASK 10:

EVALUATION OF THE LOW-INCOME SCREENING METHODOLOGY

\section{TASK 11:}

EVAJUATION OF THE LOW-INCOME PROGRAM

COLLABORATIVE PLANNING APPROACH

Prepared for

NORTHEAST UTILITIES

by

STEVEN FERREY

PROFESSOR OF ENERGY LAW

\section{DISCLAIMER}

This report was prepared as an account of work sponsored by an agency of the United States Government. Neither the United States Government nor any agency thereof, nor any of their employees, makes any warranty, express or implied, or assumes any legal liability or responsibility for the accuracy, completeness, or usefulness of any information, apparatus, product, or process disclosed, or represents that its use would not infringe privately owned rights. Reference herein to any specific commercial product, process, or service by trade name, trademark, manufacturer, or otherwise does not necessarily constitute or imply its endorsement, recommanufacturer, or otherwise does United States Government or any agency thereof. The views and opinions of authors expressed herein do not necessarily state or reflect those of the United States Government or any agency thereof. 


\section{OVERVIEN}

This evaluation of the WRAP program is designed to:

* Review the continulng relevance of the demand-side management option screening methodology for determining program configuration for services delivery, including rural populations

* Locate and analyze recent additions to the energy conservation literature, data and information that bear on design of the WRAP program

* Through interviews assess particlpant impressions of the collaborative process used to plan, develop and implement the WRAP process

This evaluation conducted by steven Ferrey \& Associates is part of a more comprehensive evaluation conducted under the management of ICF Resources, Inc. Thls Investigation was conducted primarily in 1990.

The report sections that follow are organized so that the review of the demand-side screening methodology is discussed in section 2. section 3, with multiple subparts, reviews new data In the I1terature relevant to the WRAP program. Section 4 contalns the results of the collaborative process review. 


\section{REVIEN OF THE DEMAND-SIDE SCREENING METHODOLOGY}

The demand-side screening methodology was reviewed as to its applicability to general low-1ncome and rural populations. This review constltuted three discrete tasks. Flrst, steven Ferrey \& Associates reviewed the methodology generally and its performance to rural customers; speciflcally.

second, 1nput was gathered from the staff of Technical Development Corporation which has performed survey work of program performance pursuant to Tasks 8-9 of the evaluation. Third, interviews were conducted with several persons involved in the collaborative process as to their perspectives on rural and general WRAP effectiveness. Fourth, a detalled literature review of several hundred new energy conservation articles in the literature was conducted to highlight recent developments in the state of the art relevant to low-income programs generally, and rural application speciflcally.

The results of this analysis indicates that the demand-side screening methodology still functions approprlately for general and rural low-income customers in connecticut. The program measures selected and packaged in the WRAP program are appropriate. Rural residential program measures and design are not a distinct subgroup from suburban residential low-income groups, generally. Wo literature surveyed indicates any misdirection in the program. There are program enhancements that are suggested in the literature, which are discussed in section 3. 
However, nonresidentlal rural energy conservation matters are another issue. Working farms are a distinct customer group. The current program design of $N U$ does not appear to, nor is it percelived as, adequately addressing this group. While the screening methodology only addresses residential low-income requirements, and does not include farms, there is a deficiency in the existing farm outreach and particlpation. As discussed in more detali in section 3 , there are no major revelations that indicate that the WRAP program must be revised for meeting its design goals. There are no radical advances in conservation technology that have occured in the two years since the program was first initiated. Nor are there significant changes in program cost-effectiveness. However, there is new evidence regarding program design and effectiveness that argues for some modifications to program deliver. These are discussed in the next section. 


\section{LITERATURE REVIEN}

\subsection{ORGANIZATIONAL SUMMARY}

A review of the literature in the energy efflclency fleld which has emerged since the original screening methodology was developed in 1988 reveals that there are 13 new pleces of I1terature that are relevant. None of these major pleces of research particularly 1solate rural customers. There is no major literature on rural low-income residential conservation.

However, these 13 articles provide new information on lowincome energy conservation program design and implementation. This is relevant to rural as well as urban and suburban customer applications. Each of these is summarlzed below, organized in categories as follows:

* Marketing to Low-income populations

* Energy education

* Elasticities and conservation design

* Weatherization

* Assisted housing

\subsection{MARKETING TO LOW-INCOME POPULATIONS}

3.2.1. J. Hammarlund, "Marketing Conservation in the Multifamily sector: Lessons Learned," in 1990 ACEEE Proceedings 
conservation incentives must offer at least one-third the cost of the conservation measure as a direct benefit to the multifamily stock, to be effective. Among the types of incentives, as compared to loans, cash rebates are:

* more popular

* provide a greater impact

* easler to administer

* less expensive

Effective marketing to the multifamily sector requires interface with local apartment owner assoclations. For the WRAP program, this research reinforces a direct, no-cost-to-customer energy efficiency effort. It would counsel no change in basic program design.

3.2.2 L. Berry, et al., "Marketing and Design of Resldential Energy Conservation Programs for the Elderly." Oak Rldge National Labcratory, ORNL/CON-246, 1988

Data from the RCS program indicates that low-income, elderly, multifamily and rental segments of the population are underserved by the RCS programs nationwide. Therefore, because the RCS program is subsldized by all ratepayers, there $1 \mathrm{~s}$ fustiflcation for commltting other utility funds from ratepayers to spectefic programs to address these underserved population groups.

The elderly have greater than average capacity for energy efflclency improvements. Three-fourths of the elderly are owners, causing relatively few barriers of rental housing stock. 
of those elderly who rent, a disproportionately large $22 \%$ live in public or subsidized housing. The conservation issues of subsidized housing are separately addressed in the final sectio of this paper.

On average, the elderly spend a $50 \%$ larger amount of their incomes on energy than does a typlcal household. Therefore, on these varlous grounds, the elderly should be a relatively good candidate group for energy conservation. Younger elderly (ages 60-70) are considered the most likely candidates for conservation.

The elderly live in less efflclent homes and engage in fewer conservation behaviors. This is true despite the fact that the elderly, constituting about $12 \%$ of the population in 1983, hold $40 \%$ of U,S. Einanclal assets. This report surveyed 39 programs addressing the energy needs of the elderly. A majority of the programs surveyed rely on interagency networking, presentations and referrals to ldentify the elderly candidates. Interagency networking is shown to stretch avallable resources. 


\subsection{BNERGY EDUCATION}

3.3.1 M. Qua1d, "Low Income Energy Education Programs: A Review of Evaluation Results and Methods," in 1990 ACEEE Proceedings

There has been much lsolated anecdotal evidence on the importance of education to achleve and maintain energy conservation savings. This article provides data on the progress of education as an integral component of weatherization programs. Thirty-three states offer education services in confunction with the low-income weatherization programs.

What this research provides is one of the first comprehensive attempts to isolate the impact of energy education as a conservation additive on top of the installation of conservation hardware or technlogies. It finds that low-income consumer education results in a consistent 4-8\% increase in energy conservation results when coupled with weatherization, compared to weatherization-only control groups. As a basic rule of thumb, such additional savings pay back their costs in about 2 years.

What is not known about energy education -- not unllke for conservation generally -- is the persistence of savings ov time. Measurement of these savings is now in its infancy. With high attrition and turnover in this housing stock, better measurement methodologies must be developed. 
3.3.2 M. Quaid et al, "An Evaluation of the Community Energy Workshop: An Energy Conservation Pilot Program for Low Income Households," Argonne National Laboratory Conference, 1990

In a Yakima Valley program, high-use high-arrearage customers were targeted with intensive energy education, and were thereby made eligible for extended bill payment plans. While the sample size was small, the education component seemed to foster 258 savings in confunction with weatherization, while the weatherization-only control group achleved orly $17 \%$ savings. This is almost a $50 \%$ increase in the savings achleved by weatherization alone.

3.3.3 T. Lent, "Improving the Weatherization Assistance program Through Home visit Education," in Proceedings of Argonne National Laboratory Conference, 1987

In a 1985-86 Phlladelphla, Pennsylvania study, education increased savings resulting from weatherization alone, from $12 \%$ (weatherization only) to $18 \%$ (weatherization and eduction) in gas-heated homes.

3.3.4 T. Lent, "Cutting cool Watts: Helping Low Income Philadelphlans Reduce Non-Heating Electricity Use," in 1988 ACEEE Proceedings

Another Priladelphia program demonstrated an $11 \%$ savings from education to cut non-heating electric use in high-usage lowincome households. There was no control group used in this 
latter evaluation.

3.3.5 J. Gregory \& L. Wliliams, "Fuel Savings Results:

Results of a Consumer Education Pilot study 11/86-3/88." Draft Report, Cleveland State University, 1989.

In ohio, energy education plus weatherization for low-income households resulted in a $20 \%$ savings in weather-normalized gas usage, compared to a $16 \%$ savings in the weatherlzation-only control group. This $33 \%$ increase in savings is significant and represents a less-than-two-year paybaci on the education investment.

3.3.6 P. Witte \& M. Kushler, "An Evaluation of The Michigan Low Income Weatherization Energy Education and Incentives Program." Michigan PSC, 1989

In Michigan, high-use low-income households in 1988-89, were offered education and financial incentives to conserve. This program demonstrated that this group chleved a $29 \%$ savings, compared to the weatherization-only control group's savings of $21 \%$.

In total, these six articles document the importance of energy education in achieving greater low-income conservation savings. A well designed program of energy education added to weatherization increases total savings by 33-50\%. About 70-75\% of households served by WRAP are renters. The WRAP program could improve its savings and its cost-effectiveness by implementing a 
comprehensive energy education component, above and beyond the "Energy Bingo," "Managing on a shoe string," and "Energy Care" programs.

Of particular relevance to the WRAP program, energy education appears to offer additional savings to high arrearage customers. These savings from energy education were demonstrated in gas-heated, electric-heated and non-heat electric usage.

\subsection{ELASTICITIES AND CONSERVATION DESIGN}

3.4.1 D. Schwartz \& B. True, "what Households Do When Electricity Prices Go Up -- An Econometric Analysis with Policy Implications," In 1990 ACEEE Proceedings

An econometric analysis of electric energy consumption responses to price changes reveals some interesting results for low-income customers and by age. When electricity prices Increase:

* Low-income households reduce electricity consumption more than more affluent households, for air conditioning and water heating. However, this reduction is primarily the result of behavior modification, rather than conservation investment.

* Low-Income households adopt fewer conservation investments

* Renters reduce consumption more than owners, such reduction coming from ilfestyle adjustments more than from conservation investments

* Younger households reduce electricity 
usage and undertake conservation more than older-headed households

This leads to conclusions with implications for the WRAP program. First, there is a significant untapped low-income and rental market for conservation measure insiallation. second, low-incone and tenant customers will not respond to price signals to install such measures. Third, low-income and tenant customers make greater than average 11 festyle and behavioral changes in response to higher electricity prices.

Therefore, low-income customers and tenants are doing what is available within their means to conserve. Low-income and tenant customers' conservation efforts exceed the norm in the population. Utility-sponsored efforts to install conservation measures proceed on a solid user-initiated foundation.

This Justifies an ambitious utility-sponsored effor' at weatherization and education. These automatic tenant and low. income customer efforts at lifestyle changes can be supported and reinforced by utility programs. Aggregate lifestyle and conservation measure energy savings can be counted and evaluatea as part of the cost-effectlveness of an expanded WRAP program. 


\subsection{MEATHERIZATION}

3.5.1 J. Schlegal \& S. P1gg, "The Potential for Energy Savings and Cost-Effectiveness of Low-Income Weatherization Programs: A Summary of Recent Evaluations," in 1990 ACEEE Proceedings

An evaluation of 11 low-income weatherization programs in the Mldwest during the 1980 s conducted by local agencles and utilities reveals that more recent weatherization programs achleve only a modest increase in savings per household compared to earlier efforts. The program showing the most increases in savings is the DOE weatherlzation program that has adopted a wider range of energy conservation measures.

\subsubsection{P. Gladhart \& J. Weihl, "The Effects of Low Income Weatherization on Interior Temperature, Occupant Comfort and Household Management Behavior," In 1990 ACEEE Proceedings}

Research in 10 low-1ncome homes demonstrated that weatherization causes internal temperatures to be more responsive to actual thermostat settings and less subject to fluctuations in external temperatures. occupants reported increased warmth, decreased drafts, and Improved health. Occupants had more effective control over internal temperature. Tenants experienced less need to attempt to manipulate their thermostats during the day.

There was little evidence of a "take back" effect, where occupants increased their consumption because of a lowering of the total fuel bill after weatherization. While temperature settings on thermostats increased $3 \%$ on average, the range of 
temperature settings among all units decreased by $36 \%$ and their standard deviation decreased by 38\%. This means that those units which set unusually high temperatures to attempt to counteract poorly weatherized dwellings, no longer felt this need.

The temperature set at the thermostat was more uniformly achieved throughout the dwelling after weatherizataion. Thus, over all units, a slightly higher average thermostat setting uses no more energy if it is maintained throughout the day and not cranked higher perlodically.

3.5.3 M. Haeri et al, "Towards an Optimal Mechanism for the Delivery of Low-Income Residential DSM Services," in 1990 ACEEE Proceedings

This weatherization research justifies targetirg low-income nelghborhoods for measures, rather than expending resources to qualify each household in a nelghborhood. This may be a modification of the WRAP program that should be considered as it becomes more mature.

The WRAP program operates in conjunction with conventional weatherization efforts, especially in its E1 and E2 formats. The most improvements in cost-effective operation of conservation programs are demonstrated in the DOE Weatherization Assistance Program. By operating in conjunction with the DOE program, NU activities are targeted in the most productive directions.

Because there is no demonstrable "take back" demonstrated in the literature of low-income weatherization, it is clear that all benefits can be targeted toward reduction of arrearage. This field data supports the rationale and program design of wpAP. 


\subsection{ASSISTED HOUSING}

A forthcoming report by the U.S. General Accounting office surveys the energy conservation and financial needs of low-income families in federally-assisted housing. This is a significant rental subpart of the low-income population in the N.U. service territory. A preview of this two-year study suggests what efficiency measures might best address this segment of the N.U. customer base. Public housing is a targeted subgroup evaluated in the original screening methodology. The discussion of these GAO findings, below, starts with examination of the characteristics of this subgroup.

\subsubsection{UTILITY REGULATORY BARRIERS}

Federally-assisted housing constitutes more than one-third of all. low-income rental housing in the nation. The major federally-assisted housing programs are the public housing and section 8 housing programs. There are approximately 1.25 million units of each. One-quarter of the public housing units house elderly and handicapped tenants.

construction of public housing is backed by federallyguaranteed tax exempt bonds, and owned by local government agencies. The federal Department of Housing and Urban Development (HUD) provides subsidies to local housing authorities for annual operating expenses that exceed rental receipts. Tenants, by statute, pay $30 \%$ of adjusted family income for rent and utilities. In return, local housing authorities are subject to significant federal regulation for utilities and other 
as pects of operation.

The section 8 program has several variations. The primary section 8 housing program provides subsidies to private market housing owners who rent to low-income tenants. Again here, tenants pay $30 \%$ of income for rent and utilities. The difference between this amount and a "Fair - Market Rent" level charged by the owner, is subsidized by HUD.

Energy efficiency investments offer a win-win situation to all stakeholders -- HUD, PHAs, and tenants. However the Performance Funding system (PFS) masks the incentives that would normally be perceived. Initially, in the first year of any PHA conservation savings, the PHA and HUD split the savings.1 Thereafter, over a three-year period, the rolling historic base for calculation of PFS utility subsidies progressively reflects the conservation savings realized. over a four-year period, the PHA share of the savings diminishes to zero, while the HUD share of these savings correspondingly increases to $100 \%$. PHA cashflow can actually be damaged, rather than promoted, by undertaking an energy efficiency investment under the current PFS regulatory structure.

This potentiality is caused by two elements. One is the PFS formula that directs any long-term savings to IUD at the expense of the PHA. The second is the need to finance and maintain the energy efficiency investment. Unless creative financing is

${ }^{2} 24$ C.F.R. 990.107(f) (Performance Funding Regulations). 
employed, 2 a significant net cash outflow can encumber the flid's financing of the initial efficiency investment. This is not to say that there aren't energy and dollar savings to the system as a whole. However, the PFS mechanism allocates those savings to HUD at the expense of the PHA. Without a waiver of the routine operation of the PFS mechanism, most PHAs may not perceive incentives to undertake efficiency investments. 3

\section{6 .2 POTENTIAL EFFICIENCY SAVINGS IN FEDERALLY ASSISTED HOUSING}

Utility expenses can constitute up to $50 \%$ and more of PHA operating budgets.4 since 1970, HUD has seen its share of public housing utility expenses increase from approximately $\$ 250$ million annually to over $\$ 1$ billion annually. 5 This does not count the increasing percentage of the annual utility bill borne by tenants during this period. 6 They constitute 26-42\% of PHA operating costs, representing as much as $85 \%$ of HUD operating

2 For a discussion of creative financing options, see, $S$. Ferrey, Local Government Financing: Innovative strategies for Local Government, Utilities and Nonprofit organizations (1984); see also, S. Ferrey, "Solar Banking: New Solutions to the Urban Energy Crisis," 18 Harv. J. on Legisl. 483 (1981).

${ }^{3}$ HUD has announced that it will consider regulatory waivers of PFS utility regulations on a case-by-case basis and issued proposed regulations at 54 Fed. Reg. 52000 (Dec. 19, 1989).

${ }^{4}$ W. Sherwood, et al, "CLPHA Survey of En Public Housling Authorities, 1978-1981," Report No. 82-3 (June 25, 1982 ! .

${ }^{5}$. Ritschard, et al, "Cutting Energy costs in Public Housing: Technical Issues, Institutional Barriers, and Research Needs," I.BL 19683 (1986) (unpublished), at 1 .

${ }^{6}$ This greater tenant share results, in part, from the conversions to individual metering undertaken by HUD. See, Harvard Journal article, supra note 2 , at 51-57. 
subsidies. Public housing energy costs are $65 \%$ higher than in comparable private market housing. ${ }^{7}$ The section 8 utility subsidy is of similar magnitude.

The importance of energy efficiency in assisted housing is underscored by energy use characteristics. Overall, the energy intensity of residential space is significantly higher for elderly or for poor households. 8 Most public housing was constructed prior to 1974. Almost two-thirds of all public housing units are in climate zones with more than 4,000 heating degree days. Given these circumstances, the importance of thermal integrity is paramount.

Yet public housing is some of the least well insulated housing nationwide. There is a variance by a factor of six in energy consumption per unit per square foot nationwide among public housing units. 9 Even controlling for differences in weather and heating degree days, there still exists a variation by a factor of three in the BTU energy use adjusted for weather variations and climate.

A report commissioned by HUD on public housing energy efficiency potential estimates that a complete cost-justified energy conservation program would reduce annual energy operating costs by $30 \%-60 \%$ (with an average $48 \%$ savings) depending on

7E. Mills, et al, "Deterrents to Energy Conservation Investment in Public Hoousing," 11 Energy systems and Policy, at 170 (1987).

8M. Brown, et al, ACEEE paper, 1984, at $\mathrm{H}-5$.

${ }^{9}$ W. Sherwood, et al, "CLPHA Survey of Energy Consumption in public Housing Authorities: 1978-1981," at 33, (June 25, 1982). 
project characteristics.10 These savings could be achieved tor an average investment of $\$ 800-\$ 2500$ per unit in 1980 dollars, demonstrating an average payback on investment of 6 years, with a return on investment of more than $15 \%$ annually. The cost of implementing these measures in all public housing would be $\$ 2$ billion and yield a savings of 1.5 quads.11

Massachusetts' Executive office of Community Affairs, based on actual inspections of approximately 15,000 units of stateaided public housing, found that up to a $35 \%$ savings in energy consumption could be achieved by investments in efficiency measures and tenant education.12 The data illustrate significant savings potential in heating system and building shell efficiency available from a variety of measures. Without making such an effort to distinguish building-, unit- and familyrelated characteristics, lower across-the-board utility allowances alone, however implemented, miss the goal.

\section{6 .3 UTILITY ALLOWANCES}

\subsubsection{Public Housing Utility Allowances}

The utility allowance determines the percentage of utility costs to be paid by tenants and the government, as well as priceinduced utility consumption/conservation incentives perceived by tenants......The so-called Brooke Amendment to the National Housing

10perkins \& Will, "Energy conservation for Housing: A Workbook," Report for HUD, Contract No. H-2850, 1982 , at 1-1.

11 Perkins \& will, supra, note 11 .

12 Massachusetts EOCD, "Energy Conservation Guidelines for Retrofit of State-Aided Housing," at l.1 (1977). 
Act requires that the percentage of income that public housing tenants pay for "shelter" (rent and utilities combined) be no higher than $30 \%$ of adjusted family income.13 At different times, a "reasonable" amount of utility service was distinguished by the type of utility meter serving the units and by whether the tenants were elderly households or low-income families.

Effective April 7, 1985, requirements were eased on local public housing authorities (PHAs); thereafter they were allowed to establish utility allowances on any defensible basis that they choose.14 The stated goal of these new regulations was threefold: (1) to place all tenants on relatively equal allowance footing, (2) to remove the significance of metering type in the determination of allowances, and (3) to provide tenant incentives for energy conservation,

Allowances are to be reviewed annually by the PHA. Only if rates change by $10 \%$ or more is an interim reevaluation of the allowance required under the federal regulations.15 Despite discretion, the GAO study reveals that allowances tailored to individual building and appliance efficiency characteristics are not being implemented at the local level, tenant conservation

1342 U.S.C. $1437 \mathrm{a}(\mathrm{a})$, (f) (1982); 47 Fed. Reg. 19,120-24 (1982). Tenants, in the alternative, may pay the lesser of $10 \%$ of gross income or their welfare rents provided by assistance programs. Id. Very few pay other than $30 \%$ of adjusted income. HUD, Local Housing Authority Management Handbook, Part II, Section 9, at 14 (1963); 49 Fed. Reg. 31,400-31,401 (1984).

1449 Fed. Reg. 31,399 (1984).

$15_{24}$ C.F.R. $965.478(\mathrm{~b})$. Any increase in allowances due to rate increases is now retroactive to the effective date of the rate increase. This provision was changed from a $20 \%$ increase trigger to a $10 \%$ increase trigger. 49 Fed. Reg. 31,406. 
incentives are not in place, and the goals of this 1935 regulatory reform are not being satisfied in the field.

\section{6 .3 .2 Section 8 Utility Allowances}

The section 8 housing program, in its various components, subsidizes tenancy in private market housing. The section 8 program, greatly simplified, is summarized as follows: PHAs, subject to HUD approval, establish a fair market rent in the community for housing units that landlords contractually bring into the section 8 program. This fair market rent operates as a rent ceiling. The tenant pays a statutory percentage (30\%) of adjusted family income for rent. The difference between the tenant payment and the fair market rent is covered by a HUD section 8 subsidy to the landlord.

one component of the fair market rent is the utility allowance. In the section 8 program, the PHA establishes the allowance level at community average for similar types of units. Distinctions can be made by the PHA for different basic building types and fuel types. This applies to units with individually metered utilities, which comprise almost three-quarters of Section 8 housing. 16

There is very little HUD section 8 guidance to PHAs. PHAS control tiow much of the fair market rent is allocated to utility expenses (to the tenant) and how much to rent (to the private-

16Urban Systems Research \& Engineering, Inc., "Research and Evaluation Regarding the Section 8 Housing Assistance Program, Report on section 8 Existing Fair Market Rents - Final Report," at 5-7 (June 17, 1977). 
market landlord). Since the fair market rent levels are fixed by HUD, the utility allowance is the critical variable within the control of the PHA. It determines how many residual dollars remain for actual rental payments, after utility expenses. This, in turn, determines how high a rent can be paid in the program, and what kind of private market units will participate in the section 8 program.

The section 8 utility allowance program has three salient differences from the public housing program. First, section 8 has a fair market rent ceiling; public housing does not. Second, explicit tenant utility and energy use protections drafted into regulations are more extensive for public housing tenants. Third, there is more random variation in the size, quality and energy-use characteristics of private market section 8 housing, than of public housing. 17

\subsubsection{GAO Report}

\section{6 .4 .1 Survey Methodology}

- The GAO collected 12 months of income, utility allowance and utility expense data for public and section 8 housing at 10 PHAs. The size of the initial sampling universe was reduced when four of the PHAs would not or could not provide adequate utility data. Notably, these included Boston, Los Angeles and Philadelphi... Each of these would be expected to provide data that would reflect unever urban allowance administration.

The six PHis participating for whom detailed data was

17 Id. at $5-35$. 
available include PHAs in Phoenix and Chandler, Arizona, East Detroit, Michigan, Dakota County, Minnesota, Cuyahoga, Ohio, and West Memphis, Arkansas. Sampling generally covered data for the period March 1988 to February 1989. This period was warmer than normal, thus influencing the predominant energy expense in this housing: space conditioning.

The average gross income for public housing families in the survey was $\$ 5,453$, and for section 8 households surveyed was: $\$ 6,533$. The adjusted average family income of these two survey groups was $\$ 4,543$ and $\$ 5,491$, respectively.

A total of 1,907 public and section 8 units were sampled in these 6 PHAs, highly representative of the 4,470 public housing units and 5,014 section 8 units, administered by these PHAs. A $93 \%$ level of confidence is associated with the sample data. It is important to note that this confidence level indicates that the sample represents statistically the total number of unit: for the particular PHAs from which the sample is drawn. However, because of the small number of PHAs sampled, this sample is not necessarily representative of the universe of public and section 8 units nationwide or in other PHAs.

Samples were excluded for units where occupancy changed during the study period, where 3 months or more of data were missing, ... where rent was paid on some bisis other than $30 \%$ of income, or where the unit was not occupied on the final date of the study period. More than $20 \%$ of the sample units initially selected had one or more data elements missing from the PHA records. 
In analyzing the data, the GAO team determined that PHAs committed numerous administrative and computational errors in calculating tenant adjusted incomes, utility allowances, and total rent. These errors included incorrect arithmetic calculations, use of outdated utility allowance schedules, and transcription errors. The analysis corrected these errors committed at the local PHA level. Therefore, the results demonstrate the actual rent/utility burdens, rather than the rent/utility burdens that the PHA thought it imposed.

For example, if the utility allowance was calculated too low, the effective rent/utility burden on the tenant would be greater than directed by statute. A too-low utility allowance results in the tenant paying out-of-pocket to the utility for the actual excess utility bill amount, in addition to $30 \%$ of income paid to the PHA. This inverse relationship between the utility allowance and rental payments holds true: The greater the utility allowance, the lower the shelter portion of rent paid by the tenant to the PHA.

The survey work yielded a calculated rent/utility burden (the percentage of each tenant's adjusted income devoted to shelter plus actual utility expenses). For master-metered tenants, by operational imperative, the rent burden always equals the statutury $30 \%$. There are no utility allowances nor tenantpaid utility bills. Similarly, for check metered tenants, an individual tenant's rent burden can exceed substantially, but never be less than, the $30 \%$ ceiling. This is because rebates to conserving tenants are not authorized, while high-consumption 
tenants are surcharged for high consumption. Individually metered tenants may experience a rent/utility burden that is significantly greater or less than the statutory level.

\section{6 .4 .2 Results}

The data indicate trat for public housing some PHAs mainiain allowances that, in the aggregate, achieve an average rent/utility burden across seasonal variations approximately equal to the $30 \%$ statutory command. Other PHAs maintain aggregate allowances for public housing that achieve the $30 \%$ of income threshold for part of the year, but exceed it significantly in other months.

The inadequacy of utility allowances is more apparent in section 8 than in public housing. There are fewer controls in Section 8 housing, less precise utility allowance standards, and less tenant protections, than in public housing. Most PHAs do not achieve the statutory rent/utility burden in their section 8 housing, either across the year or seasonally.

Table 1, tabulating the results of this survey, presents several interesting results. First, it is of note that there is virtually no check metered section 8 housing nationwide. Section tenants are predominantly individually metered and do not reçeive the legal protections of check and master metered tenants.

second, every PHA in the study established a more accurate aggregate utility allowance, and thus rent burden, for its public housing than for its section 8 housing. on average, the rent 
burden on section 8 tenants in a PHA is more than $20 \%$ above the statutrory ceiling. This occurs notwithstanding the fact that in this survey, the income of the average section 8 tenant (constituting the denominator for rent/utility burden calculations) was $20 \%$ more than that of the public housing tenant.

Third, as a generalization, those PHAs which do not adequately protect their tenants against seasonal utility fluctuations, do not hold tenant rent/utility burdens at the $30 \%$ level, but rather exceed this amount. This suggests that the allowance is not tracking actual utility requirements for all or part of the year. A closer examination of this data for individual PHAs reveals that those PHAs that experience seasonal variations in rent/utility burdens are climate-determined: The cold winter locations exhibit excessive rent/utility burdens in winter months, while warmer locations exhibit excessive rent/utility burdens in summer months. The allowances do not reflect actual building behavior in extreme weather months. This is especially true in private market section 8 units, which are less carefully monitored by PHAs as to their utility and rent burdens.

Fourth, the GAO data, when analyzed on a unit-by-unit basis, demonstrate that there is significant individual variation among the rent/utility burdens of individually metered households. While a few individually metered households had total rent/utility burdens slightly below the $30 \%$ threshold, some greatly exceed the statutory limit. In fact, some households in 
the sample were found during some months to spend more. than $100 \%$ of their adjusted family incomes on rent plus actual utility expenditures.

It has been suggested that PHAs, in an effort to stimulate. more participation in the section 8 program, tend to suppress the utility allowance component of fair market rent.18 This effectively gives a larger amount to the private market landlord who participates in the section 8 program. This, in turn, may bring into the section 8 market better quality housing than otherwise would be offered. Simultaneously, a suppressed utility allowance provides less to tenants, thus causing them to pay, in reality, more than the statutorily prescribed percentage of income for section 8 shelter. This operates as a largely hidden transfer payment.

Survey evidence suggests that three-quarters of section 8 tenants receive an inadequate utility allowance. Almost onethird of this group pays $100 \%$ more out-of-pocket for actual utility costs than is allowed in the section 8 regulations. The vast majority of section 8 utility scheduies previously surveyed allowed less consumption than actual utility requirements. 19

Energy efficiency, in addition to its inherent benefits, narrows the dispersion of consumption and brings back into normal range the skew of high consumption due to building- and appliancerelated factors. Energy efficiency, if comprehensively deployed,

\footnotetext{
18U.S.R.\& E., supra note 20 , at 5-4.

${ }^{19}$ Id. at 5-13-18.
} 
renderis consumption patterns more normal and less prone to extremp seasonal fluctuations, and this, in turn, would allow allowances based even on a simplistic measure of central tendency to be more "reasonable." Thus, energy efficiency in section 8 and public housing dwellings is the foundation for cost-effective improvements, as well as the key to rendering utility allowance formulae fair and reasonable.

\section{6 .5 conclusion}

Energy conservvation, as embodied in the WRAP program, constitutes a critical resource for federally assisted urban and rural housing. First, because the WRAP program does nof require building owner funding, it is particularly attractice to section 8 owners. Second, because WRAP conservation measures narrow the dispersion of consumption and normalizes consumption distribution, they inject per se more equity into public housing and Section 8 utility subsidy schemes, regardless of how they are administered. Third, because of its structure, WRAP is attractive to owners, low-income tenants and housing officials. 


\section{COLLABORATIVE PROCESS EVALUATION}

\subsection{OVERVIEW}

This task assesses the collaborative process utilized in Connecticut to engage in conservation and load management program design and implementation. Interviews were conducted with those Involved in the collaborative process and with some interest group representatives not involved in the collaborative process. All available literature regarding the collaborative process was reviewed.

4.1 .1 The Role of the Evaluator

In many ways, critiquing something as subjective as a collaborative process is a very delicate task. This dellcacy is succinctly summarized in one article on program evaluation of collaborative processes:

\footnotetext{
"The problem with such evaluations is that nobody likes bad news. As constructive as the findings may be, they are still felt as criticism by the people involved. Even more distressing, a finding of "room for improvement" can be transformed into the billy club of "not doing the Job" by organizational factions seeking a scapegoat for some issue, lobbying for an increased DSM role, or directing a reduction in DSM activities." 1
}

1. M. McRae, "Don't shoot the Messenger: Conducting DSM Process Evaluations in Inevitably Political Environments," in ACEEE Froceeding, Ṽoiume 6 , isgó. 
Perhaps it is prophetic that the quotation above is from an article entitled "Don't shoot the Messenger." It should be remembered that a process evaluation is an inherently subjective exercise. Rather than evaluating measured results, one is reporting subjective reactions to a process.

And those relaying these reactions are precisely those involved in the process. Rather than standing an objective distance from the process, they are in the middle of the process. Therefore, a process evaluation reports perceptions and interrelationships.

Comments of those interviewed may be motivated by longerstanding grievances. When participants represent different interests, there is a natural tendancy to defend one's constituent interest. While not objectively "quantifiable," the process and the reactions of those involved in the process are Important components of a collaborative approach to ut1lity issues. Perceptions motivate human behavior and are very real in their consequences. The politics of the process are of crucial importance.

\subsubsection{The Interview Process}

In this evaluation, I, as evaluator, am a "messenger." I am relaying the comments made by others, rather than initiating the critique. To the degree that those interviewed have criticisms or praise, they are reflected in this report. And some of those interviewed did have strong criticisms. I have attempted to balance comments so that the positive and the critical are set- 
out in context within a given subsection. These comments of those interviewed should be read in the context of a collaborative process that overall was successful. The feedback received is organized into the following sections:

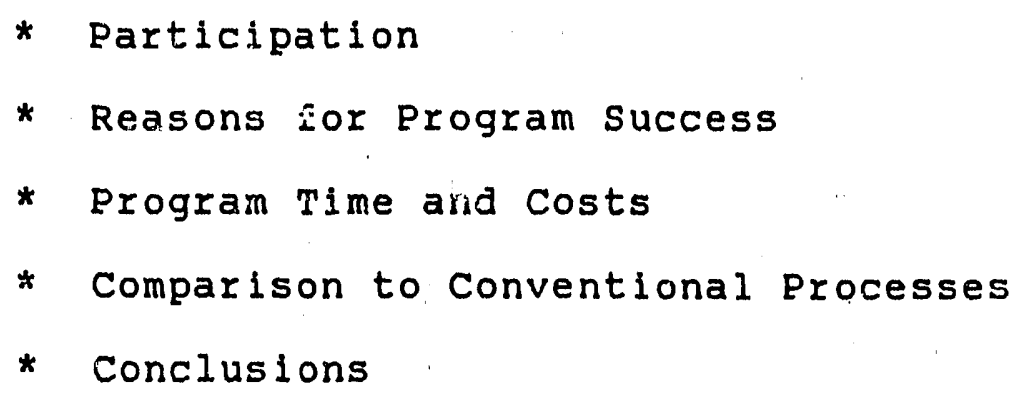

Those who were involved with various aspects of the collaborative process were interviewed as part of this exercise. Some interest group representative not explicitly a part of the collaborative process also were interviewed. All interviews wert conducted in 1990. Anonymity was guaranteed to all respondents in two regards. First, the content of comments was to be without attribution to the person who made the comment. Second, those specific persons interviewed were promised that their names would not be revealed so that a reader could not "link up" a comment with a particular interviewee.

\subsection{THE COLLABORATIVE PROCESS IN A NUTSHELL}

Northeast Utilities (NU) entered Into an agreement with the Conservation Law Foundation of New England (CLF) to design and implement conservation and load management programs on a 
consensual basis. Joining in this process were representatives from the Prosecutorial Division of the Department of Public Utility Control (DPUC), the office of Consumer counsel, and the Energy Division of the office of Policy and Managment. NU provided funds for CLF to hire a set of consultants to assist in program design and evaluation.

There were a series of meeting to design and implement conservation programs for different customer market segments. All parties worked to ldentify target markets, conservation technologies and delivery systems for different markets. The draft measures were evaluated in terms of cost-benefit analysis and resource allocation. Programs on which there was consensus were presented to the DPUC and implemented.

\subsection{PARTICIPATION}

\subsubsection{Participants}

Several of those inside and outside the collaborative process believed that the cross-section of groups participating in the collaborative process was insufficient. No organized private consumer groups were represented. Private low-income groups were not represented. No public groups other than CLF were represented. This did not allow the inclusion of all customer perspectives in the opinion of some of those interviewed. By contrast, the Massachusetts collaborative process included representatives of more purlic interest groups. 
some commenters observed that they belleved that this lack of a robust cross-section of groups skewed program design. They stated that they belleved that there was not sufficient concern about residential and equity issues. They stated thät they belleved that there was too narrow a focus on the "biggest bang for the buck," and a resultant emphasis on commercial and industrlal sector programs. Some went even further and suggested that residential consumers received insufficient benefits. There was also criticism volced as to the emphasis on reaching the electric heating customer among those residential participants.

some of this was blamed on the lack of public group or academic participation in the collaborative process. Others also blamed this on the particular consultants employed by the group. Those consultants were thought by some to be too "technical" or engineering-oriented, with insufficlent regard for equity and program balance. More than one commenter noted that the consultants had ruffled some feathers. One commenter noted that mistrust increased over time in the group, rather than abating as would be expected. This perspective was not shared by some others.

However, other interviewees, while conceding that there was more focus on commerclal and industrlal programs, thought that this was appropriate in the early phases of program development. These same persons belleved that no additional interest groups should have been at the table, and that the consultants performed adequately.

Therefore, there seem to be two divlded oplnions of the collaborative process. One group is satisfied with all elements, 
althought noting some room for improvement. The other group is not satisfied with the process, with the consultants, and in some cases, with the results.

\section{3 .2 Northeast Utilities Staff}

The program staff at NU involved in low-Income programs was uniformly praised by all interviewees. The one concern raised was that not enough corporate committement was made to low-income conservation concerns at the highest levels of the Company. Many of those interviewed stated that they favored more institutional commltments to conservation at the middle and upper management levels.

\subsection{REASONS FOR PROGRAM SUCCESS}

4.4.1 Progress Toward Goals

Several interviewees commented that the reason that the collaborative process worked was because of pressure from the DPUC and Office of the Commissioner of Revenue. This pressure was attributed with credit for motivating all the parties to undertake good-faith collaborative efforts.

Several commenters suggested that there were times when there was a worry about "backsliding." Backsliding was described as a process where members of the collaborative process thought that commitment had been achieved with all parties at an 
appropriate level of each organization, but work on exact implementation was delayed when middle level personnel attempted to move forwara thereafter. Some participants believed that there was resistance at these middle levels after there was commitment from top levels. This backsliding was blamed for some of the significant time commitment made by the parties. The NU staff working on low-income programs was universally praised.

\subsubsection{Specific Proqrams}

The WRAP program was universally praised by all those interviewed. This was not true of other programs developed by the collaborative process. This is an interesting observation, given that NU originated the idea for the WRAP program prior to creation of the collaborative process.

The same was not said for rural programs, which were thought: not to be well designed. The farm program was singled out by many of those interviewed as one which needed reworking. This area is one that was targeted for improvement. However, commenters believed that rural low-income residential customers were adequately served by existing programs. 


\subsection{PROGRAM TIME AND COSTS}

The amount of time devoted was critlcized by some as excessive for the results achleved. While negotiations proceeded, time was lost during whlch conservation measures could have been implemented. There is a lost opportunity cost when Installation of conservation measures $1 \mathrm{~s}$ delayed. The costs of the collaborative process were criticlzed as exceeding those of conventional rate case proceedings. A commenter noted that "a lot of time was spent going nowhere." As noted below, there were others who belleved that the amount of time could be Justifled. There was critlcism of the rush to push so many programs into operation rapidly at one time. Program design and ramp-up was criticized as accelerated more to meet political objectives than motivated by wise program planning. Adequate time to design and review programs was found lacking. "sign off" often was required of particlpants before adequate program review was completed and before intelligent declsions could be made, . accorlding to some. some commented that they signed-off on programs rapldiy for political reasons, without adequate time for review. 


\subsection{EOMPARISON TO CONVENTIONAL PROCESSES}

\subsubsection{Criticisms of Collaborative Process}

There were mixed opinions as to how this process worked in comparison to conventional contested rate proceeding forums. One group of opinion thought that the collaborative process had not worked well: It consumed a slgniflcant block of time, did not "heal" old wounds, in some ways stralned patience among particlpants, and was inefficient. Some particlpants belleved that they were "more coopted" than in conventional rate proceedings.

They believed that the ability iegitimately to criticize adversaries was compromised. This was thought by some to be especially true when an agency head supported the collaborative process, when the agency staff did not support that process. The staff were therefore given the task of negotiating something that they may not have wholeheartedly supported. Their interest therefore waned, minimizing their formative influence. They became more reactive. At least one participant commented that the same amount of money could have been better spent on program outreach, rather than on the process.

The solution advocated by one commenter was more participation -- not in the collaborative process but rather in conventional ratemaking litigation. The problem was laid to the lack of public interest groups that actively participate in the conventional ratemaking process. Rather than have the utility fund a public interest group's collaborative process 
particiaption costs, it was suggested that more widespread participation should be encouraged/funded in the conventional ratemaking process.

\subsubsection{Support for the Collaborative process}

A different perspective was volced by others. These others thought that the collaborative process did perform better than conventional rate proceedings. They noted that it broke new. ground. They commented that the collaborative process substitutes for two conventional processes. First, it substitutes for the contested ratemaking proceeding; second, it substitutes for the later phase of program development and implementation. The latter is particularly time consuming, but is not often tabulated in the efforts necessary to implement and deliver programs.

Those of this latter view admit that there are contentious feelings between some of those participating in the collaborative process. As one commenter stated: "Of course there were some bad feelings, they were borne of decades of hate, this is not an inherently pleasant process."

By entering the process at an earlier stage, opinion is not as resolutely formed. Therefore, there is an opportunity to truly influence program deslgn. In conventional proceedings, the utility enters the process by an application and is already prepared to defend that application and 1 ts proposals. One commenter noted that if all time of all utility and nonutility 
parties were computed, the time committment of all parties would not be greater than that devoted to the collaborative process.

\section{6 .3 Use of $\underline{\text { Consultants }}$}

There was criticlsm of the consultants employed. The criticisms included that friends and favored consultants were used. The projects were not put out to bid. The choices of consultants were criticized for a fallure to utilize regional consulting talent; instead a preference for non-New England consultants was noted.

External consultants were noted to have less "feel" for the region, to be less accessible and to incur greater travel expenses. Criticism was voiced by some for "freezing out" certain consultants. While this was justified by a desire to move quickly, some commenters believed that the choice of consultants was not objective. Others thought the consulting pool as a whole was satisfactory. 


\subsection{EONCLUSIONS}

\section{7 .1 summary}

Opinion about the collaborative process divided into two general views. One view was satisfled by the process as to both its goals and the realization of those goals. The time commitrient was deemed fustified. This same group was satisfled with the particular participants and would not wish to add to nor subtract from those who particlpated. They thought that a larger representation of public groups would make consensus more difficult.

The other group of opinion sees this as the precise nature of the problem: The small number of participants, while making decislonmaking easier, did not adequately reflect all interests that have a stake in the process and in the expenditure of utility funds for conservation. As an outgrowth, consultants were selected and employed in a fashion that some commenters belleved was not approprlate.

To some degree, these differences of opinion are expected. There has been a history of disagreement among many of the participants. One would not expect that to vanish merely because a different process for dispute resolution is employed. of note, noone has pulled out of the collaborative process.

This author had an opportunity to review three negotiation processes supported by the Edison Electric Institute in the mid1980 s involving electric utilities in Massachusetts, New Mexico and Colarado. While those processes were much more inclusive of 
groups and interests, they achleved less. Judged against those efforts, the Connecticut collaborative process has many elements to recommend it. As in any process, there is always room for refinement and improvement in later iterations. And it appears that such improvements could be made to the connecticut process.

\subsubsection{Possible Program Changes}

Since the collaborative process is well underway, it may not be appropriate to now attempt to make changes. However, suggestions may be appropriate for future iterations of this process. If one wanted to act on the constructive criticisms revealed in this evaluation, the following program changes -- one change drawn from each of the report sections above - could be considered:

* Participation: Include representatives of unrepresented constituencies

* Program success: Work to achieve middlelevel support for program conservation goalsin all participating organizations

* Program time and costs: spend resources to find ways to limit the expenditure of time by participants; this may include more strategic use of consultants

* Process: Utilize local New England consultants where there is local expertise 

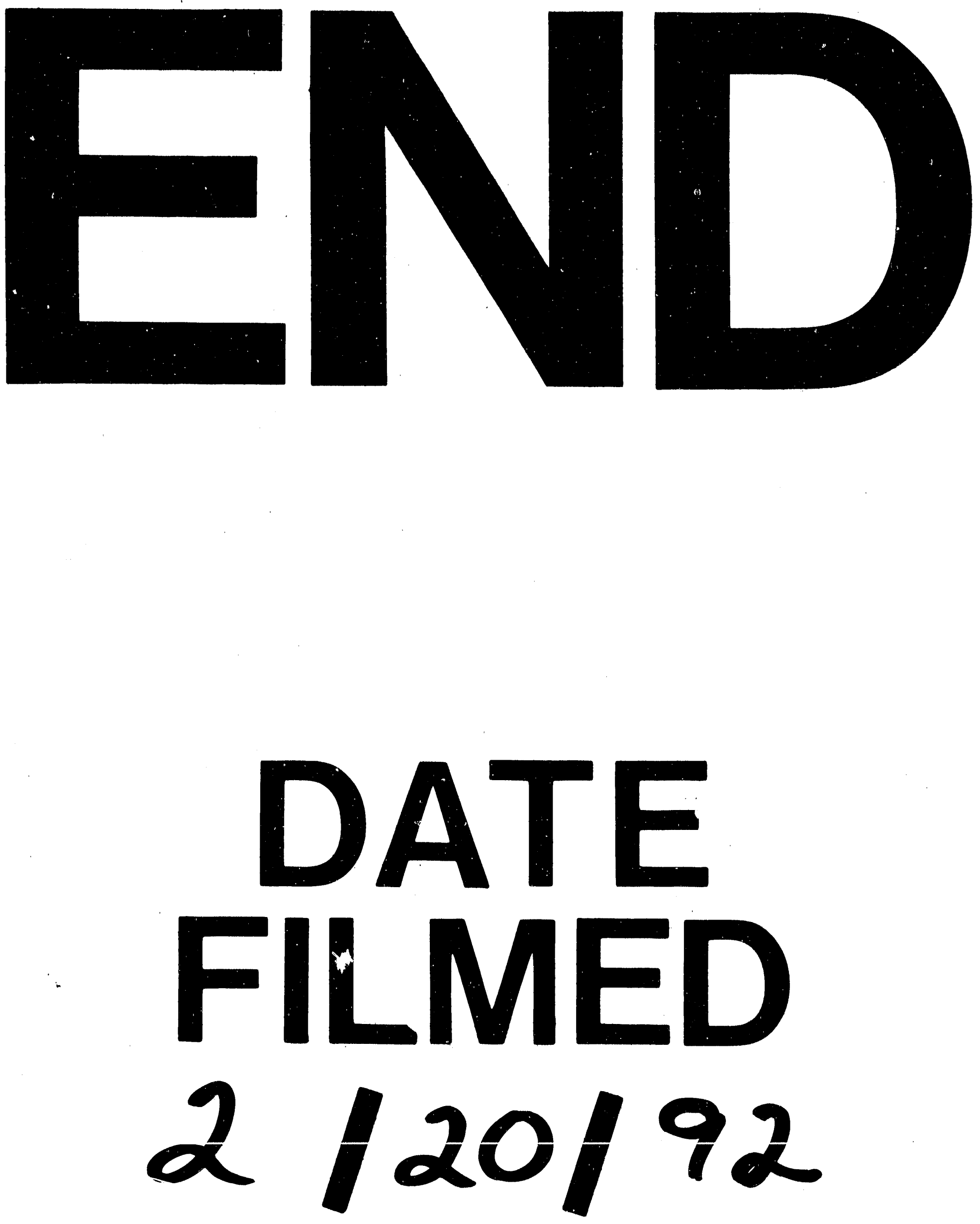
